\title{
The Development of Mathematics Teaching Materials through Geogebra Software to Improve Learning Independence
}

\author{
Eri Saputra $^{1 *}$, and Effan Fahrizal ${ }^{2}$ \\ ${ }^{1}$ Department of Mathematics Education, Universitas Malikussaleh, Aceh Utara, Indonesia \\ *Corresponding author: erisaputra@unimal.ac.id | Phone Number: +62-85262213786
}

\section{ARTICLE HISTORY}

Received : 12 September 2019

Revised : 28 September 2019

Accepted : 15 October 2019

\section{KEYWORDS}

Geogebra;

Teaching Materials;

Learning Independence;

\begin{abstract}
Geogebra is software designed to solve geometry, calculus and algebra material as well as applications for designing spaces and buildings. The purpose of this research is to produce teaching material products through Geogebra software in mathematics courses that can be utilized in learning. The stages in this research include: (1) the stage of developing teaching material products, (2) the testing phase of teaching materials products (3) the analysis of increasing student's independence. Product development and level of practicability of teaching materials is validated by material experts, media experts, lecturers as users, and trials of teaching material products. Qualitative data is used as a consideration in teaching material products to make revisions while quantitative data is analysed by statistical tests to see an increase in student self-independence. Based on the test results of experts teaching materials developed for trials in the field. Experts recommendations about teaching materials are appropriate for use and revision. After the revision is issued, try the field that involving students, the results of the test items about the reliability level of 0.734 so that teaching materials could be used for research instrumentts. The average value and standard deviation of the normalized gain values for the experimental class are 0.812 and 0.139 while the control class are 0.731 and 0.198 . The analysis result of the questionnaire is that there is an increase in self-independence in study of the students in Architecture Study Program, Engineering Faculty, Malikussaleh University
\end{abstract}

\section{INTRODUCTION}

Nowadays, technology has become one of the sources of learning that is in great demand by students. So that the quality of education needs an adjustment. This requires the educators to make innovation and creativity in the implementation of learning process by developing learning systems that are technology-based, student-oriented and facilitate a challenging, active, creative, innovative, effective and fun learning (Fazar, et al 2016).

The use of information technology enables the learning process individually so that a process of independent in learning is created and better than conventional systems. Over time, learning in conventional becoming obsolete and switch to using technology.

Various creativities are created so that there will be students who want to advance in the field of science. This has implications for the learning media. According to Nur (2016), learning media is a means/aids for educators to convey messages or information so that they can be interesting and well received by students. Learning objectives can be created by choosing the right media. The use of instructional media is as a tool in preparing teaching materials and in the learning process to be more effective and efficient. One of the main tasks of educators before conducting lectures is formulating instruc- tional goals, making lesson plans, compiling lecture contracts and making teaching materials. Ministry of National Education (2006b: 1) defines teaching material as a form of material used to assist instructors in carrying out teaching and learning activities in class whether in the form of written materials such as handouts, books, modules, student worksheets, brochures, leaflets, wallcharts, and unwritten materials such as videos/films, VCDs, radios, cassettes, computer-based interactive CDs and the internet.

Teaching materials designed by educator will determine the success of students in learning. The teaching materials or subject matter can also be designed and arranged systematically that allows students to learn independently. The teaching materials allow the educators and learners to be more focused and achieve all the competencies.

According to Prastowo (2011), good teaching materials include learning instructions, competencies to be achieved, lesson contents, supporting information, exercises, work instructions, evaluations and responses to evaluation results. Teaching material for students serves as learning media that helps them to learn independently without any time limit or having to meet face to face with lecturer and can guide student point of view in understanding a concept and provide a 
complete picture of a material. According to Sumeda (in Bawono, 2015), mathematics is generally defined as a field of science that studies patterns of structure, change and space. So, Geogebra software is very suitable as mathematics learning media. The Geogebra software was developed by Markus Hohenwater at University of Florida Atlantic America in 2001.

Geogebra is an abbreviation of geometry and algebra. The selection of geogebra as a medium of mathematics learning because geogebra is an open source application, which means the software is free. Geogebra can make a variety of presentations such as mathematical objects because geogebra is a dynamic geometry software that helps to form points, lines and all curves. Geogebra is software designed to create teaching material such as geometry, calculus and algebra. In addition, Geogebra can also design spatial shapes and buildings so that they are easy to apply to architecture students at Malikussaleh University.

Geogebra software is very useful for demonstrating and visualizing mathematical concepts, especially geometry objects (Mahmudi, 2011). The use of geogebra learning media provides the opportunity for students to learn discovery and educators to act as mentors who provide active learning so as to create independent learning.

According to Mahmudi (2010), the use of geogebra program provides several benefits, including:

1. Paintings are produced quickly and thoroughly compared to using pencil, ruler, or compasses

2. The existence of animation and manipulation movements (dragging) in geogebra program can provide clearer visual experiences for students in understanding mathematical concepts.

3. Can be used as feedback/evaluation to ensure that the painting is correct

4. Make it easier for educators/students to investigate or show the characteristics that apply to a mathematical object

By using the geogebra software, students are also expected to be able to learn independently even without formal learning where they can explore their capabilities. If at any time the students want to review the material that has been learned, they can open a video tutorial in this program without having to ask.

Basir in Ningsih and Nurrahmah (2016) states that learning independence is defined as a learning process that occurs in a person. In the efforts to achieve the learning goals, that person is required to be active individually or not dependent on others, including not dependent on the teacher. Independent learning is one of the factors determining the student success in learning, so that this self-independence attitude is required by anyone who wants to achieve success in life.

Desmita in Suhendri and Mardalena (2013) states that independence is usually have several characteristics including: able to determine one destiny, creative and initiative, well-behaved, responsible, self- restrained, good decision making, and able to solve problems without any influence from other people. This shows that the independence of learning can be seen from opinion, attitude, and behaviour. The results of research conducted by Asngari (2015) suggested that the geogebra program can be used as a medium of mathematics learning to demonstrate or visualize as well as learning aids to construct mathematical concepts.

Nopiyanti (2012), in her research found that geogebra software-assisted learning devices can be used as a guide for students to develop learning materials in accordance with the learning characteristics that are emphasized both in terms of development and processes procedures to see the quality of the learning materials. Dikovic (2009) GeoGebra provides multiple representations of mathematical objects, it can help students discover connections between mathematical objects and their graphical representation.

Velichova (2011) Said that GeoGebra is suitable for manufacturing teaching materials and can be used in e-learning solutions as a dynamic interactive platform for calculations and picture. Many studies and researches have proved the effectiveness of the use of Geogebra software in the teaching and learning of mathematics, including the studies of Preiner (2008), Saha, et.al (2010), Zengin, et. al., (2012), Arbain and Shukor (2015), Fajarrallah (2016), and teh study of Nisiyatussani, et.al (2018). Therefore this research is titled The Development of Mathematics Teaching Materials through Geogebra Software to Improve Learning Independence.

\section{RESEARCH METHODS}

This study aims to produce a product that is a teaching material by utilizing geogebra program in learning. This research used the design of development research using descriptive quantitative research methods. The research method was conducted to see the increase in student learning independence in Architecture Study Program at Faculty of Engineering Malikussaleh University in mathematics courses through the use of information technology- based learning media geogebra software.

In this research, subjects were divided into two groups: experimental group and control group. The design of this research is (a) the experimental class was started with initial test (pre-test) then a treatment was given (testing of geogebra software) and continued with final test (post-test) (b) the control class was started with initial test (pre-test) but no treatment was given (in statistics, a control class does not have theory testing or geogebra software was not used) and continued with final test (post-test). The population in this study is students of architecture study programs at the Faculty of Engineering, Malikussaleh University. The sampling is done by random sampling. The sample is experimental and control group. The instrument of this study is a modified student learning independence questionnaire, a mathematical test in initial and final tests and an interview guide.

The learning independence questionnaire was first checked and given input by experts before being distributed. After the instrument revised based on the input of experts, then tested to the students to see the validity of the instrument.

Data collection techniques used in this study were questionnaire, test and interview. Mathematics test was used to assess students' cognitive domain. Meanwhile, to see the students independence of mathematics learning, a learning independence scale questionnaire were used and continued with exploration through interviews. The learning outcome test and the questionnaire were analyzed in parametric test, average difference test, prerequisite test and normality test by using chi-square formula, then proceed with homegeneity test using a filter test with normalized gain score.

\section{RESULTS AND DISCUSSION}

This study used geogebra application as a learning medium. The following is geogebra menu display for drawing geometry objects: 


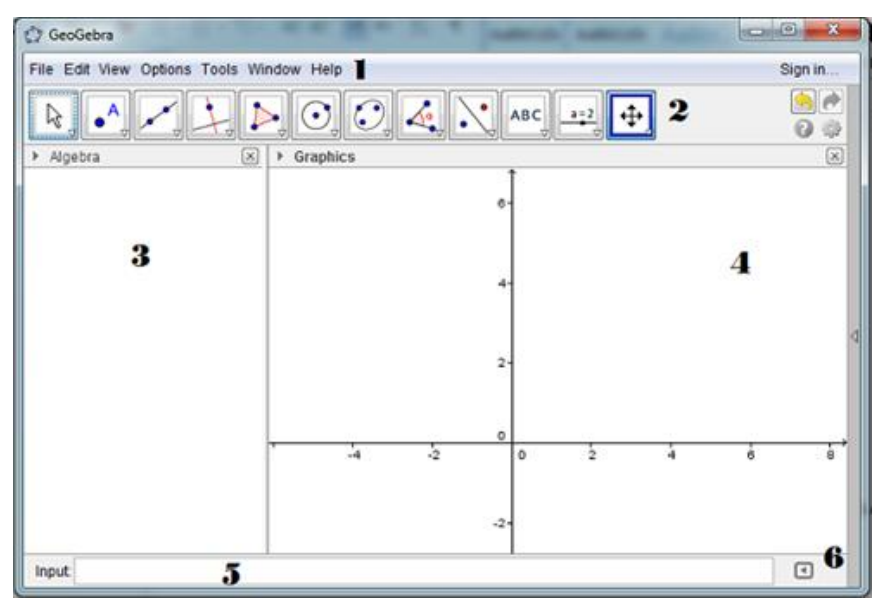

Fig 1. Display of the Geogebra Menu

The explanation of the front view on geogebra is as follows:

1. The geogebra menu consists of files, edit, view, options, tools, windows and help

2. The toolbar icon is useful as a helper tool for working on graphics

3. The algebra column, as an algebra window such as points, functions, lines etc.

4. A geogebra worksheet that displays a graph of an equation

5. Input bar column used as the input place for a function, point, line, etc.

Symbols in geogebra is about algebra, geometry and statistics.

The study was conducted in the Architecture Study Program at Faculty of Engineering Malikussaleh University in mathematics subject. Before conducting research, initial observations were conducted to detect problems that occur in mathematics subject. The research involved students as research object about enhancing students independent learning through geogebra application. The data obtained is based on the results of questionnaires, observations, interviews, and mathematics learning outcomes.

The next stage was to analyse the results of the questionnaire and conclude the results of observations and interviews, as well as learning outcomes (cognitive abilities) of architecture students. The results of the analysis and conclusions becomes the basic material for designing architecture student mathematics teaching materials.

\subsection{Results}

The development of mathematics teaching materials by using geogebra application have the following stages and steps: identifying teaching material requirements, designing teaching material, validating the design, revising the design, trying the product, revising the product, refining the product, producing teaching material.

\section{a. Designing teaching material}

Based on data analysis that architecture students in mathematics courses have never used teaching materials based on geogebra applications. Therefore, teaching materials based on geogebra applications are designed so that students can improve their independence in learning mathematics

b. Teaching materials

In compiling teaching materials, the researcher studied deeper and more broadly about mathematics teaching materials based on geogebra applications, then validated the content and design, then evaluated the content and design as needed. The teaching materials are equipped with instructions for use or rules for teaching materials based on geogebra. In addition, the teaching material also comes with a description of the contents. It also contains student activity sheets and worksheets that includes individual tasks to work independently and task groups to measure the level of cognitive and student ability. There is a worksheet contains answer key of the task to be done independently so that the students can match with the provided answers. The teaching material is equipped with an evaluation sheet containing questions that must be done for quiz and midterm test.

c. Teaching Material Test Result Data

Before trial conducted validated teaching materials based on consideration of competent experts that have expertise in the field of mathematics teaching material. Then the teaching material was tested on engineering faculty students then analyzed overall both based on statistics, namely the questions used were measured validity, reliability, different power and level of difficulty, analysis of the results of the test instrument also to determine whether each item was good and feasible to use while based on descriptive reviewed the content, depth and breadth of the material, and the suitability of the material in the mathematics teaching material.

Based on the test results of experts teaching materials developed for trials in the field. Experts recommendations about teaching materials are appropriate for use and revision. After being revised, it was tried out in the field involving students, the results of the test items about the reliability level of 0.734 so that teaching materials could be used for research instruments.

d. Learning achievement test data

The quiz test was held as an evaluation of lectures using teaching materials based on geogebra application to measure the cognitive abilities of architecture students of the Engineering Faculty of the University of Malikusaleh.

e. Interview result

Interviews were conducted to evaluate the use of geogebra-based teaching materials as consideration for teaching materials evaluation, shortcoming and input for improvement.

Student interview results

Question: How did you feel when you took classes using geogebra-based teaching materials?

Conclusion of the Answer: Students felt happy learning mathematics by using geogebrabased teaching materials.

Question: Were there any difficulties in using geogebra based application teaching materials?

Conclusion of the answers: Lack of complete instructions when taking the quiz test. 
Question: What is the role of instructional materials based on geogebra applications in facilitating mathematics learning?

Conclusion of the answers: It was very easy to learn mathematics.

Question: Did geogebra application-based teaching materials have a positive influence on the independence of learning mathematics?

Conclusion of the answers: All students had opinions that geogebra application-based teaching materials gave positive influence on mathematics learning independence.

f. Analysis of Learning Independence Assessment Based on observation of student learning independence, the following data are obtained: Based on observation data, it is identified that the students of architecture faculty of engineering, on the first indicator, $88 \%$ of students have a strong desire in learning mathematics with geogebra-based teaching materials. In the second indicator, $84 \%$ of students were responsible for each learning activity. In the third indicator, $89 \%$ of students were able to take decisions and initiatives to deal with problems. And in the fourth indicator, $83 \%$ students had confidence in carrying out the tasks independently.

g. The results of the practicability analysis of teaching materials based on geogebra applications

The results of the assessment of the geogebra application-based teaching material get $84.38 \%$ achievement level which means the geogebra-based teaching material in the category of very practicable. The evaluation results of the practicability of teaching materials by the validator gave some input for improvement on the teaching materials. Geogebra application-based teaching materials are very helpful for students learning mathematics in terms of the delivery of material. The appearance of teaching materials is good so that makes students interested in learning but there are some features and languages that must be improved for the perfection of teaching materials. The improvements are that there must be more questions in the question bank. The teaching material should be equipped with problem examples, practice questions, question cards, evaluation, self-reflection, and self-assessment with the aim of having feedback on students. In fact, students understood the material easily with geogebra application. This can be seen from the mathematics test scores with an average rating of 89.05. Geogebra application have several advantages such as evaluation with interesting and varied questions.

h. Hypothesis testing

The mean score of the experimental class pre-test questionnaire is 67,16 and the control class is 65,63 . The average post- test questionnaire score of the experimental and control class is 87,3 and 73,15 . The average value and standard deviation of the normalized gain values for the experimental class are 0.812 and 0.139 while the control class are 0.731 and 0.198. After testing the statistical hypothesis of the learning independence questionnaire, the normalized gain was obtained.
There was an increase in learning independence of the architecture students of Engineering Faculty Malikussaleh University through the development of teaching materials based on geogebra software.

The advantages of geogebra based teaching materials

a. Easy to use for students, both individually and in groups.

b. Equipped with interesting animations and images.

c. Equipped with simple experiments.

d. Can be used as a source of independent learning.

Weakness in Geogebra application-based teaching materials is that when typing incorrect numbers or symbols in the application, it will not get an answer.

Some of the works of students in independent learning using Geogebra software:

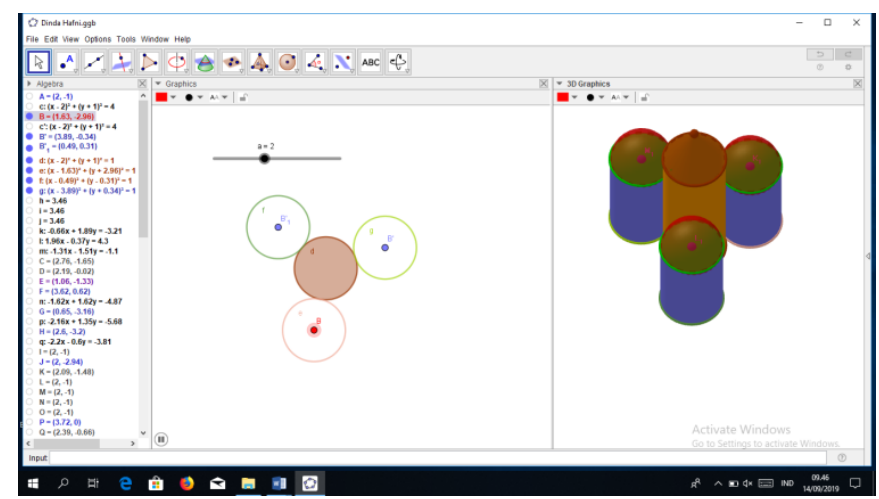

Fig 2. Rotating Circle Animation.

In this animation, students made a spinning circle. The students could define the equation of a circle, the area of a tube, the area of a half circle and a cone.

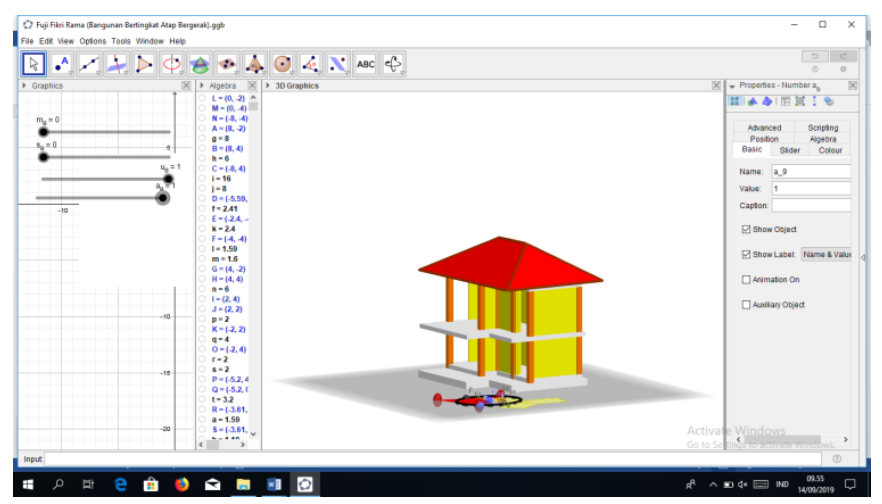

Fig 3. A 2-storey Building 


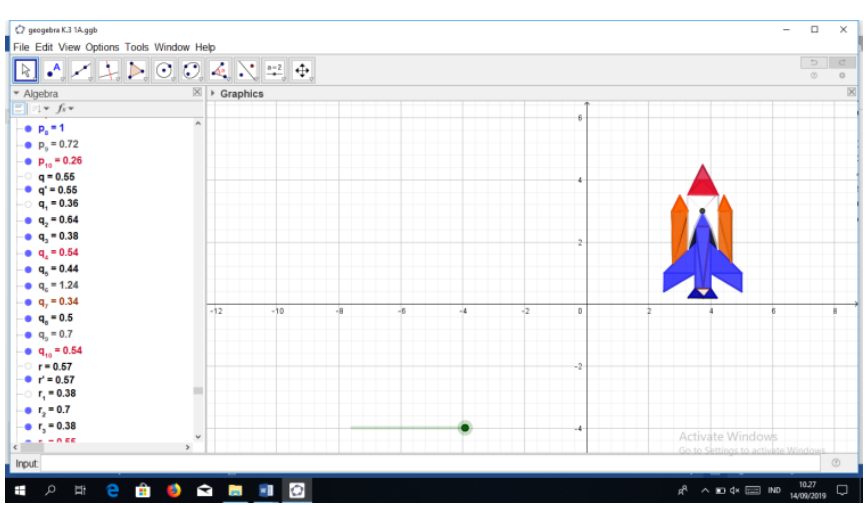

Fig 4. Spacecraft Animation

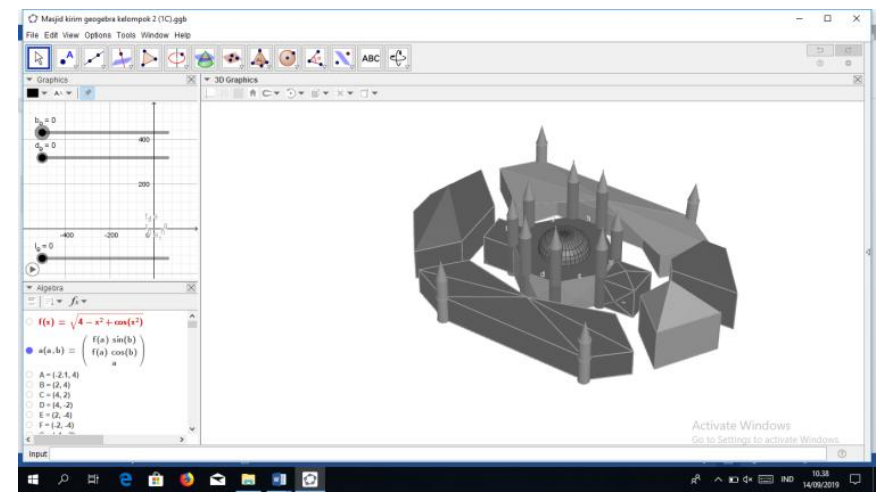

Fig 5. Mosque

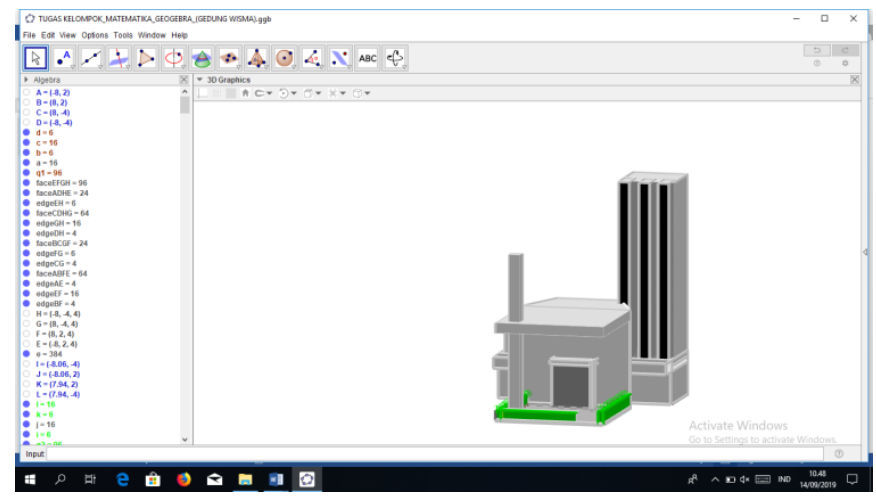

Fig 6. Hotel Building

\section{ACKNOWLEDGEMENTS}

This study was supported by a grant from the Ministry of Research, Technology and Higher Education. Thank you to our colleagues from Malikussaleh University for all the support and encouragement that greatly helped this research.

\section{REFERENCES}

Arbain, Nazihatulhasanah., Shukor, Nurbiha A. (2015). The effects of GeoGebra on students achievement. Procedia Social and Behavioral Sciences 172 ( 2015 ) 208 - 214.

Asngari, Dian Romadhoni. (2015). Penggunaan Geogebra dalam
Pembelajaran Geometri. Seminar Nasional Matematika dan Pendidikan Matematika. 299-302

Bawono, Edo. (2015) Pengaruh Metode Accelerated Learning Berbantu Jurnal Belajar dan Geogebra 3D Ditinjau Dari Kemampuan Pemahaman Matematik Terhadap Hasil Belajar Pada Ruang Dimensi Tiga. Jurnal Aksioma. 6(2).69-77

Depdiknas. 2006b. Pedoman Memilih dan Menyusun Bahan Ajar. Jakarta: Depdiknas

Dikovic, Ljubica. (2009). Implementing Dynamic Mathematics Resources with Geogebra at the College Lever. International Journal of Emerging Technologies in Learning (iJET). 4(3). 51-54

Farrajallah, Abd-Alkreem. (2016). The Impact of the Employment of Geogebra Software in Acquiring Some Visual Thinking Skills and On the Academic Achievement among 8th Grade Students. IOSR Journal of Mathematics, 12 ( 2), 53-64.

Fazar, Ibnu., Zulkardi., Somakin. (2016) Pengembangan Bahan Ajar Program Linear Menggunakan Aplikasi Geogebra Berbantuan Android di Sekolah Menengah Atas. JPPM, 9(1), 6-11.

Hohenwarter, Markur., Lavicza, Z. (2007). Mathematics teacher development with ICT: Towards an international Geogeba institute. Paper presented at the proceedings of the British Society for research in to learning mathematics. University of Northampto, UK: BSLRM., 27 (3).

Hohenwater, Markus., Hohenwarter, Judith., Kreis, Yves., Lavicza, Zsolt. (2008). Teaching and Calculus With Free Dynamic Mathematics Software Geogebra. 11th International Congress on Mathematical Educations (ICME 11) Mexico. 1-9

Lestari, Ika. (2013).Pengembangan Bahan Ajar Berbasis Kompetensi: Sesuai dengan Kurikulum Tingkat Satuan Pendidikan. Padang : Akademia Permata

Lestari, Indri. (2018) Pengembangan Bahan Ajar Matematika dengan Memanfaatkan Geogebra Untuk Meningkatkan Pemahaman Konsep. GAUSS: Jurnal Pendidikan Matematika. 01(01). 26-36.

Prastowo, A. (2011). Panduan Kreatif Membuat Bahan Ajar Inovatif Yogyakarta : Pusat Diva Press

Mahmudi, Ali. (2010). Pemanfaatan Geogebra dalam Pembelajaran Matematik. FPMIPA. Universitas Negeri Yogyakarata.

Mahmudi, Ali. (2010). Membelajarkan Geometri dengan Program GeoGebra. Seminar Nasional Matematika dan Pendidikan Matematika 2010. Pendidikan Matematika FMIPA UNY.

Ningsih, Rita., \& Nurrahmah, Arfatin. (2016). Pengaruh Kemandirian Belajar dan Perhatian Orang Tua Terhadap Prestasi Belajar Matematika. Jurnal Formatif. 6(1). 73-84

Nisiyatussani., Ayuningtyas, Vidya., Fathurrohman, Maman., Anriani, Nurul. (2018). Geogebra Applets Design and Development for Junior High School Students to Learn Quadrilateral Mathematics Concepts. Journal on Mathematics Education.9(1). 27-40.

Nopiyanti, Ni Luh Putu Ayu. (2012). Pengembangan Perangkat Pembelajaran Geometri Berbantuan Geogebra Dalam Upaya Meningkatkan Keterlibatan Dan Prestasi Belajar Matematika Siswa Kelas VII. Jurnal Pendidikan dan 
Pembelajaran Matematika Indonesia. 1(2), 1-12.

Nur, Isman M. (2016) Pemanfaatan Program Geogebra dalam pembelajran Matematika. Delta-pi: Jurnal Matematika dan Pendidikan Matematika. 5(1). 10-19

Preiner, J. (2008). Introducing dynamic mathematics software to mathematics teachers: The case of Geogebra. $\mathrm{PhD}$ thesis, Faculty of Natural Science, University of Salzburg.

Saha, Royati Abdul., Ayub, Ahmad Fauzi Mohd., Tarmizi, Rohani Ahmad. (2010). The Effects of GeoGebra on Mathematics Achievement, Enlightening Coordinate Geometry Learning. Procedia Social and Behavioral Schilences, 8 (2010), pp. 686-693.

Suhendri, Huri., \& Mardalena, Tuti. (2013) Pengaruh Metode Pembelajaran Problem Solving Terhadap Hasil Belajar Matematika Ditinjau Dari Kemandirian Belajar. Jurnal Formatif. 3(2). 105-114.

Velicova, Daniela. (2011). Interactive Maths with GeoGebra. International Journal of Emerging Technologies in Learning (iJET). 6(1). 31-35.

Zengin, Yilmaz., Furkan, Hasan., Kutluca, Tamer. (2012), The effect of dynamic mathematics software geogebra on student achievement in teaching of trigonometry, Procedia - Scocial and Behavioral Sciences 31 (2012) 183-187. 